\title{
Evaluating the Impact of Weather and Climate Information Utilization on Adoption of Climate-Smart Technologies Among Smallholder Farmers in Tambacounda and Kolda Regions, (Senegal)
}

\author{
Beckie Nantongo $^{1 *} \quad$ Joseph Ssekandi $^{1} \quad$ Ablaye Ngom $^{2} \quad$ Birane Dieng $^{2} \quad$ Ndongo Diouf $^{2}$ \\ Jules Diouf ${ }^{2} \quad$ Kandioura Noba ${ }^{2}$. \\ 1. Faculty of Agriculture, Uganda Martyrs University, Nkozi, P.O Box, 5498, Kampala, Uganda \\ 2. Faculty of science and technology, Department de Biologie vegetale, Université cheikh Anta Diop Dakar, P.O Box \\ 5005, Dakar- Fann Senegal \\ *Email of the corresponding author: nntngbck@yahoo.com
}

\begin{abstract}
:
Senegal is subjected to climate change and unstable weather conditions of the Sahel zone causing adverse negative effects on the agricultural sector and biodiversity. Weather and climate information is one of the requirements for effective adoption of climate-smart agriculture in Senegal, where Agriculture employs approximately $65 \%$ of the total population. This study evaluated the impact of weather information utilization on adoption of climate-smart technologies among smallholder farmers using a case study of Tambacounda and Kolda regions in Senegal. The study aimed at establishing the level of accessibility, understandability, usability of weather information and examined the extent to which utilization of weather information impacts the adoption of Climate-smart agriculture technologies among smallholder farmers in Tambacounda and Kolda. For this study, questionnaires were administered to 341 purposively sampled households with the help of department extension workers and local leaders. The study findings show that while smallholder farmers accessed weather information through traditional and modern media sources like radio, television, and telephone, understandability and usability of the weather and climate information received were low. Overall utilization of weather and climate information was low. Also, the overall adoption rate of climate-smart agriculture technologies was low. Utilization of weather and climate information was constrained by language problems, failure to comprehend the information, difficulty in understanding forecast terminology, inability to respond to weather and climate information in terms of farming equipment and other inputs, poor packaging of information, and user unfriendliness of weather and climate information in the study area. The regression model results $(\mathrm{F}=22.203, \mathrm{P}=.028)$ were within the significant level $(\mathrm{p}<0.05)$, which means that accessibility, understandability, and usability of weather forecasts were appropriate predictors of adoption of climate smart technologies among smallholder farmers. A new and effective weather information delivery system is proposed and provision of weather-based advisory services to the farming communities.
\end{abstract}

Keywords: Adoption, Climate/weather information, Climate-smart technologies, Smallholder farmers, Senegal

DOI: $10.7176 / \mathrm{JEES} / 11-2-05$

Publication date: February $28^{\text {th }} 2021$

\section{Introduction}

The effects of climate change in Africa are evident and are causing a big challenge on human health, forestry, water resources, fisheries, agriculture, and the entire food security systems in the twenty-first century (Cherotich et al., 2012; FAO, 2013; Barnard et al., 2015). These effects manifest in terms of floods, extreme heat or drought thus threatening the role agriculture plays in promoting food security, poverty reduction, community resilience and economic growth, more so amidst smallholder farmers (Barnard et al., 2015; Altieri and Nicholls, 2017; Belay et al., 2017). Providing real-time weather and climate information services could lessen vulnerability and enhance community resilience. This is because agricultural decisions in sub-Saharan Africa are heavily reliant on this information (Sivakumar, 2006; Mutoko et al., 2015).

Despite efforts to invest in weather and climate information services, smallholder farmers in many developing countries seldom utilize such products for farm-level decision-making (Ndambiri et al., 2013). This is mainly due to lack of adaptability of the information to local conditions, difficulties in accessing localized information (drought occurrences and rainfall cessation) on time and in a format that decision-makers could easily understand (Kadi et al., 2011). DeLonge et al. (2016) assert that ensuring that farmers understand weather and climate information disseminated could guide their decisions especially when it comes to what climate-smart agriculture (CSA) practice to adopt. 
Senegal has remained vulnerable to episodic climate shocks (primarily drought). Most of the country is subject to unstable weather conditions of the Sahel zone, which is characterized by a single rainy season that lasts for up to three months (LeRouxRutledge et al., 2010). Food crises continue to hit some parts of the country (particularly in the dry areas), with resultant loss of lives and livelihoods, and a cycle of disaster relief that compete with long-term developments (Zougmore et al., 2016). These vulnerabilities have affected agricultural productivity and Senegal's Gross Domestic Product (GDP). This is evident in the steep reduction of the agricultural sector contribution to Senegal's GDP from $25 \%$ in 2007 to $17.5 \%$ in 2015 (FAO, 2015). The continued decrease in agricultural production has made Senegal susceptible to continuous reliance upon food aid and imported food (LeRoux-Rutledge et al., 2010).

A National Adaptation Plan of Action (NAPA) was developed in 2006 by the Senegal government as a response to climate change (UNDP, 2006). It should be noted that even though there is a policy framework, Senegal is still vulnerable to lack of adequate weather information/data on climate change vulnerability (IPCC., 2017). There is minimal utilization of weather and climatic information which decreases the resilience of agricultural systems to climate change (Mutoko et al., 2015; Serra and Mckune, 2016).

According to a research conducted by Ou et al.,(2018) in West Africa, an average of $71-95 \%$ of the farmers are enormously affected by climate change and are aware of its effect. This makes adoption of CSA technologies very essential in their farming decision making if they are to continue producing food. Despite the potential benefits CSA could offer Senegal, it is confronted with many challenges this is coupled with limited studies on the adoption of climate information services.

The overall usefulness of weather and climate forecast is therefore determined by several factors. Firstly, farmers must have access. Secondly, there must be sufficient ability to decode climatic forecasts. Finally, there must be sufficient motivation to effect changes in their production systems in line with the dictates of the forecasts. This study, therefore, evaluated the impact of weather information utilization on the adoption of climate-smart technologies by smallholder farmers in Senegal.

\subsection{Material and methods}

\subsection{Description of area of study}

The study was conducted in Tambacounda and Kolda regions of Senegal (Fig. 1). Tambacounda is physically the largest of Senegal's 14 regions situated on the Sahelian plains of eastern Senegal with a tropical savanna climate. Kolda is located in southern Senegal, a region known historically and popularly as Haute Casamance. Both regions have two seasons, the wet season lasts for five months, from June through October. The dry season begins in November and ends in May. The annual average temperature is $81.9^{\circ} \mathrm{F}$ with a maximum of $104^{\circ} \mathrm{F}$ in April, May, and October, and a minimum of $59^{\circ} \mathrm{F}$ in January and February (Bacci et al., 2013; ANSD, 2015).

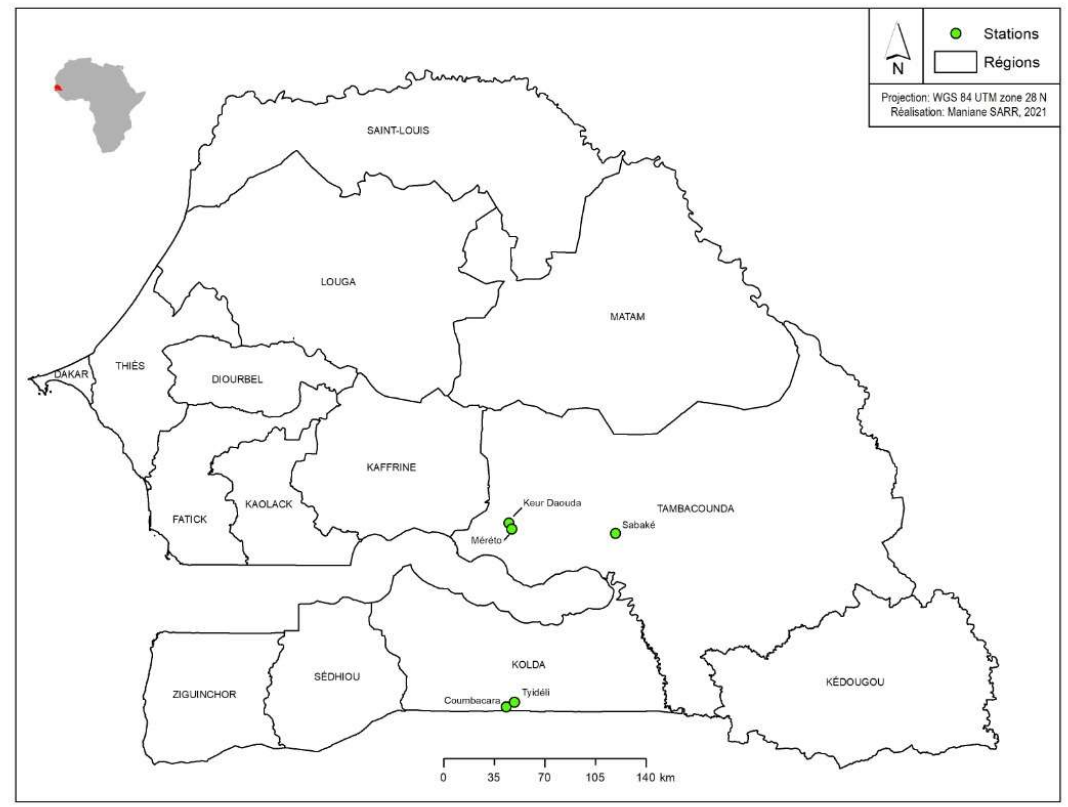

Figure 1: Map of study area 


\subsection{Interview and survey procedure 2.2.1. Sampling procedure}

Stratification was done using existing administrative areas. In this case, seven strata were formed out of the administrative areas from both Tambacounda and Kolda Regions. In each stratum, purposive sampling was used to select households that had smallholder farmers. Purposive sampling was carried out with the help of department extension workers and local leaders in listing those households which had smallholder farmers who were selected for this study. Then proportionate sampling was used in ensuring that each rural commune is represented proportionately according to the number of smallholder farmers residing there.

\subsubsection{Data collection}

Quantitative data were collected using an interviewer-administered questionnaire with both closed and open-ended questions while Key Informant interview guides were used to carry out key informant interviews between July and August 2020. The study population included 341 smallholder farmers, 11 local leaders, and 4 extension workers. The smallholder farmers were chosen because they form a big portion of the respondents targeted by the study. The local leaders were chosen because they are aware of the extent to which weather information is disseminated in the area. Extension workers from the Local or regional Government were also chosen because they are aware of the extent to which weather information was being utilized and its influence on adoption of climate-smart technologies in the area.

\subsection{Data analysis}

After data collection, the data were coded and entered into SPSS 20 (Statistics Package for Social Sciences) software and descriptive statistics were generated and interpreted. A linear regression model below was used to present results of the influence of utilization of weather and climate information and adoption of climate-smart agricultural (CSA) practices

$Y=\beta_{0}+\beta_{1} X_{1}+\beta_{2} X_{2}+\beta_{3} X_{3}+\varepsilon$

In the equation $\mathrm{Y}$ - represents adoption of CSA, $\beta_{0}-$ is a Constant, $\mathrm{X}_{1}$ - accessibility $\mathrm{X}_{2}$ - understandability, $\mathrm{X}_{3}$-usability, $\beta_{1}$, $B_{2}, \beta_{3}$ represent Coefficients of the independent variable. The error term assumed is $\varepsilon$.

\subsection{Results and Discussion}

\subsection{Demographic characteristics of sample farmers}

Socio-demographic characteristics are essential in any form of empirical study. An analysis of the demography of the population under study provides the basis of understanding how best they can be integrated into the study findings and their impact on the final study results. The respondents constituted $70.1 \%$ male, females on the other hand were represented by $29.9 \%$. This, therefore, implies that at least all sexes were represented which means that all views of both sexes were well integrated into the findings. It should be noted that when the gender of respondents is established in adoption studies of this nature, it becomes essential to know the influencing pillar, its significance, and the extent to which they determine the utilization of weather and climate information in households (see Table 1). The age ranged from 20 to 58 years and above, with an average of 43.6 years approximately. Most of the respondents (29.2\%) were 28-37 years old. $25.8 \%$ were in the age group of 38-47 years. Cumulatively, it can be concluded that over $50 \%$ of the respondents were above 40years. Age is highly considered in adoption studies because younger people have less experience and are more open to identify and take up new technologies. Concerning education, $34.6 \%$ of the respondents were illiterate, while $26.4 \%$ had attended religion schools and $38.9 \%$ received formal education. Education is believed to have a role in influencing household heads' income, adoption of technologies, and as a whole the socioeconomic status of the family. The majority of respondents $(85.9 \%)$ were low-income earners, $12 \%$ were categorized as moderate-income earners and only $2.1 \%$ were in the category of high-income earners. Most of the lowest income earners were found in Tambacounda more than Kolda Region. The findings imply that low-income earners are less likely to have the ability to seek weather and climate information because however much it is free information, the process or mediums of communication need money. The less the ability of low-income earners to reach out to different communication channels, the less they are likely to be aware of the weather and climate forecasts and this has a long-term effect on adoption of CSA practices. Regarding marital status, $92.1 \%$ of the sampled population were married. Based on earlier adoption studies, the ability of married households to adopt given practices is much higher than any other marital status. This is because households with married partners tend to have the required labor force to implement a given practice. It was reported that $35.2 \%$ of the respondents had been in crop farming for the last 16 years and above, followed by $15.5 \%$ who had spent $11-15 y$ years. Wholesomely above $50 \%$ of the farmers had been in crop farming for over 10years. This implied that they had the required experience regarding utilization or non-utilization of weather and climate information. In many cases, time spent in farming is associated with adoption or non-adoption of a given technology. This is highly dependent on the experience serial farmers have gone through. The average number of members per household was 12.25. The average land size was 5 hectares. This is an 
implication that various CSA practices can easily be integrated into their farming system. Therefore, with a smaller land size, the possibility of adopting CSA is low.

Table 1: Socio-demographic characteristics of Respondent

\begin{tabular}{|c|c|c|c|c|}
\hline \multirow[t]{2}{*}{ variable } & \multirow[t]{2}{*}{ indicator } & \multicolumn{2}{|l|}{ Location } & \multirow[t]{2}{*}{ Average } \\
\hline & & Tambacounda & Kolda & \\
\hline \multirow[t]{2}{*}{ Sex respondents } & Male & 130 & 109 & $239(70.1 \%)$ \\
\hline & Female & 40 & 62 & $102(29.9 \%)$ \\
\hline \multirow[t]{6}{*}{ Age of respondents } & Below 18yrs & 3 & 2 & $5(1.5 \%)$ \\
\hline & $18-27 \mathrm{yrs}$ & 15 & 16 & $31(9.1 \%)$ \\
\hline & $28-37 \mathrm{yrs}$ & 50 & 51 & $101(29.2 \%)$ \\
\hline & $38-47 y r s$ & 45 & 43 & $88(25.8 \%)$ \\
\hline & $48-57 \mathrm{yrs}$ & 33 & 35 & $68(19.9 \%)$ \\
\hline & $58 \mathrm{yrs}++$ & 24 & 24 & $48(14.1 \%)$ \\
\hline \multirow[t]{5}{*}{ Education of respondents } & None & 48 & 70 & $118(34.6 \%)$ \\
\hline & Primary & 45 & 42 & $87(25.5 \%)$ \\
\hline & Secondary & 16 & 22 & $38(11.1 \%)$ \\
\hline & University & 6 & 2 & $8(2.3 \%)$ \\
\hline & Religion & 55 & 35 & $90(26.4 \%)$ \\
\hline \multirow{3}{*}{$\begin{array}{l}\text { Household income of the } \\
\text { respondents }\end{array}$} & Low & 150 & 143 & $293(85.9 \%)$ \\
\hline & Moderate & 18 & 23 & $41(12 \%)$ \\
\hline & High & 2 & 5 & $7(2.1 \%)$ \\
\hline \multirow{4}{*}{$\begin{array}{l}\text { Marital status of the } \\
\text { respondents }\end{array}$} & Married & 156 & 158 & $314(92.1 \%)$ \\
\hline & Divorced/separated & 1 & 1 & $2(0.6 \%)$ \\
\hline & Widow/widower & 3 & 6 & $9(2.6 \%)$ \\
\hline & Never married & 10 & 6 & $16(4.7 \%)$ \\
\hline \multirow[t]{5}{*}{ Time spent in crop farming } & $<1 \mathrm{yr}$ & 0 & 1 & $1(0.3 \%)$ \\
\hline & $1-5 y r s$ & 10 & 8 & $18(5.3 \%)$ \\
\hline & 6-10yrs & 12 & 14 & $26(7.6 \%)$ \\
\hline & $11-15 y r s$ & 25 & 28 & $53(15.5 \%)$ \\
\hline & $16 \mathrm{yrs}++$ & 123 & 120 & $243(35.2 \%)$ \\
\hline \multirow{7}{*}{$\begin{array}{l}\text { Household size } \\
\text { (member) }\end{array}$} & $<1-5$ & 5 & 4 & $9(2.6 \%)$ \\
\hline & $6-10$ & 69 & 69 & $138(40.5 \%)$ \\
\hline & $11-15$ & 41 & 46 & $87(25.5 \%)$ \\
\hline & $16-20$ & 31 & 30 & $61(17.9 \%)$ \\
\hline & $21-25$ & 16 & 13 & $29(3.8 \%)$ \\
\hline & $26-30$ & 3 & 2 & $5(1.5 \%)$ \\
\hline & Above 30 & 5 & 7 & $12(3.5 \%)$ \\
\hline \multirow[t]{6}{*}{ Land size (ha) } & $k=1.00$ & 11.8 & 36.3 & 24.0 \\
\hline & $1.01-9.00$ & 61.2 & 55.0 & 58.1 \\
\hline & $9.01-17.00$ & 20.0 & 7.6 & 13.8 \\
\hline & $17.01-25.00$ & 5.3 & .6 & 2.9 \\
\hline & $25.01-33.00$ & 1.8 & 0 & 9 \\
\hline & $49.01+$ & 0 & .6 & .3 \\
\hline
\end{tabular}




\subsection{Access to and sources of climate and weather information}

As indicated in Table 2, survey results show that $76.2 \%$ of respondents accessed weather information were as $23.8 \%$ do not access it. Most of the weather information was accessed through traditional sources especially radio and television which were $71.3 \%$ and $29 \%$ respectively. Modern media was also used especially telephones through SMS and social media at a percentage of $28.2 \%$. This indicates that traditional media which is radio and television are mostly used and preferred in accessing weather information in Tambacounda and Kolda while modern media is used less. The above findings seem to coincide with earlier scholars who indicated that radio, television are traditional mechanisms and key means for transmitting weather observations and forecasts to agricultural stakeholders. They further indicated that mobile phone and internet use for weather information are still emerging concepts in developing countries because most rural farmers are not able to navigate the functions of the mobile phones and can only be effectively used if weather information is sent by voice messages in a language they understand (Feleke, 2015; Anuga and Gordon, 2016; Serra and Mckune, 2016; Anuga et al., 2019).

Table 2: Access to sources of climate and weather information

\begin{tabular}{|c|c|c|c|c|}
\hline & & \multicolumn{2}{|l|}{ Location } & \multirow[b]{2}{*}{ Average } \\
\hline & & Tambacounda & Kolda & \\
\hline \multirow[b]{2}{*}{ Access weather information } & No & 40 & 41 & $81(23.8 \%)$ \\
\hline & Yes & 130 & 130 & $260(76.2 \%)$ \\
\hline \multicolumn{5}{|l|}{ a. Sources of weather information } \\
\hline \multirow[t]{2}{*}{ Radio } & No & 48 & 50 & $98(28.7 \%)$ \\
\hline & Yes & 122 & 121 & $243(71.3 \%)$ \\
\hline \multirow[t]{2}{*}{ Television } & No & 120 & 122 & $242(71 \%)$ \\
\hline & Yes & 50 & 49 & $99(29 \%)$ \\
\hline \multirow[t]{2}{*}{ Newspapers } & No & 166 & 171 & $337(98.8 \%)$ \\
\hline & Yes & 4 & 0 & $4(1.2 \%)$ \\
\hline \multirow[t]{2}{*}{ Magazine } & No & 170 & 171 & $341(100 \%)$ \\
\hline & Yes & 0 & 0 & $0(0 \%)$ \\
\hline \multirow[t]{2}{*}{ Telephone/social media } & No & 122 & 123 & $245(71.8 \%)$ \\
\hline & Yes & 48 & 48 & $96(28.2 \%)$ \\
\hline
\end{tabular}

\subsection{Utilization of climate and weather information}

Utilization of climate and weather information was measured using three factors which were accessibility, understandability, and usability of climate and weather information. Each of these factors was measured using three indicators. Theoretically, accessibility to weather and climate information was studied using three indicators, that is; access to communication channels or sources of weather and climate information, information seeking behavior, and the time when the forecasts are communicated. Secondly, Understandability of climate and weather information was measured using language used in weather forecast dissemination, information clarity, and level of understanding of forecast terminologies. Lastly, usability of climate and weather information was measured by three indicators which included; ability to respond to weather information in terms of farming equipment and inputs, packaging of weather information, and user-friendliness of weather information.

In general, it was established that $74.8 \%$ of smallholder farmers had access to weather and climate information in Tambacounda and Kolda Regions, Senegal (Table 3). This is depicted in the majority of respondents agreeing that they had high levels of accessing weather and climate information through different communication channels $(65.6 \%)$, took an extra effort to seek this information $(73.5 \%)$ and the timing of this kind of information was extremely right $(85.3 \%)$. This implies that there is proper timing of communicating weather forecasts in Tambacounda and Kolda regions. Timing is an important element in utilization of weather and climate information because when this kind of information is untimely, it becomes less important. The results further indicate a non-satisfactory understanding of weather information disseminated by $73.7 \%$ of the respondents. This can be associated with the high trends of poor quality of weather and climate information transmitted in Tambacounda and Kolda Regions Senegal. The results show that on average the language used in forecast dissemination was easily understood by $33.4 \%$ of the respondents, weather and climate information was clear to only $21.8 \%$ and forecast terminologies were easily understood by only $23.8 \%$ of the respondents. Usability of weather and climate information among smallholder farmers was rated at $35 \%$ whereas the non-use was at $65 \%$. This implied that the majority of farmers had no required ability to use this information. For instance, the ability to incorporate weather information in their farming decision process was refuted by $61.4 \%$ of respondents. Packaging of weather information was rated unfavorable by $67.4 \%$ of respondents and user-friendliness of weather and climate information was refuted by $66.2 \%$. This implied that there are significant limitations in using weather and climate information 
in terms of farming equipment like ploughs and new crop varieties. It was revealed that to a large extent smallholder farmer did not utilize weather information in Tambacounda and Kolda Regions, Senegal. This was reflected in the fact that $74.8 \%$ of smallholder farmers had accessibility to weather and climate information. However, $35 \%$ could use weather and climate information, only $26.3 \%$ understood weather and climate information in Tambacounda and Kolda Regions, Senegal. This meant that on average at least $45.4 \%$ of respondents utilized weather information while $54.6 \%$ did not utilize climate and weather information in Tambacounda and Kolda Regions, Senegal. Studies by Sovacool et al., (2017) and Taneja et al.,(2019) established that the less utilization of weather and climate forecasts was due to the wrong timing of communicating forecasts to farmers. Though this was not the case in Tambacounda and Kolda since the majority of the respondents indicated that they received the weather information on time. The major challenge was the inability to understand due to the complexity of forecast terminologies and language used. Previous scholars assert that understanding weather information calls for taking the extra mile to seek training or advice from fellow farmers, extension workers as far as agriculture is concerned (DeLonge et al., 2016; Oladele et al., 2019). The absence of a center for coordination and downscaling weather information at the local level greatly affects the farmers' ability to understand and utilize weather information (Feleke, 2015). This is supported by Oladele et al.,(2019) who ascertained that weather and climate forecasts have little importance unless they are tailored enough to be used operationally in the farming decision. Another challenge limiting the utilization of weather information was limited usability. This was due to lack of farming equipment and inputs like improved seed variety and fertilizers, poor packaging of the information, and user-unfriendliness. According to Phillipo et al.,(2015), smallholder farmers are not necessarily lazy in responding to weather and climate information but they lack the needed tools and equipment to implement. They further argued that many farmers tend to leave the poorly packaged forecasts and rely on indigenous knowledge which they are culturally oriented to. However, Nyanga et al., (2011) on contrary argued that it's not the lack of equipment that hinders smallholder farmers to respond to weather and climate information but it is a lack of grasp.

Table 3: Utilization of climate and weather information in Tambacounda and Kolda

\begin{tabular}{|l|l|l|}
\hline Factors considered & YES (\%) & NO (\%) \\
\hline i. Accessibility of weather and climate information & & \\
\hline Accessibility of communication channels used & 65.6 & 34.4 \\
\hline Information seeking behavior & 73.5 & 26.5 \\
\hline Timing of weather forecast & 85.3 & 14.7 \\
\hline Overall mean & $\mathbf{7 4 . 8}$ & $\mathbf{2 5 . 2}$ \\
\hline ii. Understandability of climate and weather information & & 66.6 \\
\hline Language used easily understood & 33.4 & 78.2 \\
\hline Information clarity & 21.8 & 76.2 \\
\hline Forecast terminologies easily understood & 23.8 & $\mathbf{7 3 . 7}$ \\
\hline Overall mean & $\mathbf{2 6 . 3}$ & \\
\hline iii. & & 61.4 \\
\hline $\begin{array}{l}\text { Ability to respond to weather information in terms of farming equipment and } \\
\text { other inputs }\end{array}$ & 38.6 & \\
\hline Packaging of weather information & 32.6 & 67.4 \\
\hline User friendliness of weather information & 33.8 & 66.2 \\
\hline Overall mean & $\mathbf{3 5}$ & $\mathbf{6 5}$ \\
\hline & $\mathbf{4 5 . 4}$ & $\mathbf{5 4 . 6}$ \\
\hline
\end{tabular}

\subsection{Adoption of climate-smart agricultural practices}

The results show that $70.1 \%$ of the respondents had adopted at least one of CSA practices while $29.9 \%$ had not adopted any of the CSA practices (Table 4). The practices mostly adopted were, intercropping (71.8\%), crop rotation (65.5\%), those that based their choice of harvesting dates on weather and climate information (67.7\%), and use Post-harvest technologies (67.7\%). However other practices were employed at a low rate. $4.1 \%$ were employing minimum tillage, mulching (2.3\%), diversification of livestock and crop farming (29.4\%), irrigation (27.9\%), application of fertilizers (29\%). The overall mean shows that adoption of CSA practices is reflected among $41.6 \%$ of the respondents while $58.4 \%$ had not adopted CSA practices in their farming decisions. This implies that accessibility, information understandability and usability (utilization of weather and climate information) does not independently lead to adoption of climate-smart crop production practices. Meaning that adoption of CSA has to be attributed to a combination of other factors besides utilization of weather and climate information. 
Table 4: Adoption and of climate smart agriculture practices in Tambacounda and Kolda

\begin{tabular}{|c|c|c|c|c|}
\hline \multirow{2}{*}{\multicolumn{2}{|c|}{ Adoption of Climate smart agriculture technologies }} & \multicolumn{2}{|l|}{ Location } & \multirow[b]{2}{*}{ Average } \\
\hline & & Tambacounda & Kolda & \\
\hline \multirow{2}{*}{ I have adopted climate-smart crop production practices } & No & 51 & 51 & $102(29.9 \%)$ \\
\hline & Yes & 119 & 120 & $239(70.1 \%)$ \\
\hline \multirow{2}{*}{$\begin{array}{l}\text { My choice of land preparation dates is guided by weather and climate } \\
\text { information }\end{array}$} & $\mathrm{eNo}$ & 44 & 55 & $99(29 \%)$ \\
\hline & Yes & 126 & 116 & $242(71 \%)$ \\
\hline \multirow{2}{*}{$\begin{array}{l}\text { I utilize weather and climate information to guide my choice of planting } \\
\text { dates }\end{array}$} & $\mathrm{gNo}$ & 49 & 64 & $113(33 \%)$ \\
\hline & Yes & 121 & 107 & $228(67 \%)$ \\
\hline \multirow{2}{*}{$\begin{array}{l}\text { Weather and climate information guides my choice of crop varieties (e.g. } \\
\text { drought-tolerant, early maturing, disease-resistant) }\end{array}$} & No & 48 & 57 & $105(30.8 \%)$ \\
\hline & Yes & 122 & 114 & $236(69.2 \%)$ \\
\hline \multirow[t]{2}{*}{ I have learnt to use cover crops } & No & 45 & 54 & $99(29 \%)$ \\
\hline & Yes & 125 & 117 & $242(71 \%)$ \\
\hline \multirow[t]{2}{*}{ I practice intercropping at my farm } & No & 47 & 49 & $96(28.2 \%)$ \\
\hline & Yes & 123 & 122 & $245(71.8 \%)$ \\
\hline \multirow[t]{2}{*}{ I engage in crop rotation at my farm } & No & 118 & 119 & $104(34.5 \%)$ \\
\hline & Yes & 52 & 52 & $237(65.5 \%)$ \\
\hline \multirow[b]{2}{*}{ Minimum tillage used in my farm } & No & 164 & 163 & $327(95.9 \%)$ \\
\hline & Yes & 6 & 8 & $14(4.1 \%)$ \\
\hline \multirow[b]{2}{*}{ I utilize mulching at my farm } & No & 169 & 164 & $333(97.7 \%)$ \\
\hline & Yes & 1 & 7 & $8(2.3 \%)$ \\
\hline \multirow[b]{2}{*}{ I diversify livestock and crop farming at my farm } & No & 124 & 120 & $244(70.6 \%)$ \\
\hline & Yes & 46 & 51 & $97(29.4 \%)$ \\
\hline \multirow[t]{2}{*}{ I use irrigation technology at my farm } & No & 123 & 123 & $246(72.1 \%)$ \\
\hline & Yes & 47 & 48 & $95(27.9 \%)$ \\
\hline \multirow[t]{2}{*}{ I can now successfully apply fertilizers for better crop production } & No & 122 & 120 & $242(71 \%)$ \\
\hline & Yes & 48 & 51 & $99(29 \%)$ \\
\hline \multirow[t]{2}{*}{ I have planted new trees which are friendly to my crops } & No & 131 & 123 & $254(74.5 \%)$ \\
\hline & Yes & 39 & 48 & $87(25.5 \%)$ \\
\hline \multirow{2}{*}{$\begin{array}{l}\text { My choice of harvesting dates is guided by weather and climate } \\
\text { information }\end{array}$} & No & 61 & 49 & $110(32.3 \%)$ \\
\hline & Yes & 109 & 122 & $231(67.7 \%)$ \\
\hline \multirow[t]{2}{*}{ I use Post-harvest technologies at my farm } & No & 61 & 49 & $110(32.3 \%)$ \\
\hline & Yes & 109 & 122 & $231(67.7 \%)$ \\
\hline \multicolumn{5}{|l|}{ Overall Mean (\%) } \\
\hline No & & & & $58.4 \%$ \\
\hline Yes & & & & $41.6 \%$ \\
\hline
\end{tabular}

3.5 Utilization of climate and weather information and adoption of climate-smart agriculture technologies.

Generally, the chi-square test indicated that all the independent sub-variables were found to have a significant relationship with the adoption of CSA practices (see table 5). Access to communication channels used was found to have a significant relationship with the adoption of CSA practices $\left(\chi^{2} 2.67, \mathrm{P}=0.017^{* *}\right)$. This was indicated by $55.7 \%$ of smallholder famers who adopted CSA had access to communication channels used to disseminate weather information. Information seeking behavior and adoption of CSA was significant $\left(\chi^{2} 2.91, \mathrm{P}=0.015^{* *}\right)$. This was indicated by $56.3 \%$ of smallholder famers who endeavored to invest an effort in seeking climate and weather information adopted CSA practices. Timing of forecast and adoption of CSA was significant $\left(\chi^{2} 2.52, \mathrm{P}=0.026^{* *}\right)$. This was indicated by $54.5 \%$ of smallholder famers who had timely weather information adopted CSA practices. For understandability of weather forecasts; the language used and adoption of CSA practices was significant $\left(\chi^{2} 2.82, \mathrm{P}=0.009^{* *}\right), 57.2 \%$ of smallholder farmers admitted that they understood the language employed in communicating weather forecasts which contributed on adoption of CSA. Information clarity and adoption of CSA was significant at $\left(\chi^{2} 1.71, \mathrm{P}=0.015^{* *}\right), 56.3 \%$ of smallholder farmers admitted that weather information provided is clear and this had contributed to adoption of CSA. Forecast terminologies and adoption of CSA was significant at $\left(\chi^{2} 1.21, \mathrm{P}=0.007^{* *}\right)$, $55.1 \%$ of smallholder farmers had adopted CSA due to forecast terminologies which were understandable. while for usability of weather forecasts, ability to respond to weather forecasts and adoption of CSA practices was significant at $\left(\chi^{2} 2.13\right.$, 
$\left.\mathrm{P}=0.009^{* *}\right), 51.9 \%$ of smallholder farmers had adopted CSA due to their ability exercised in responding to weather forecast. Packaging of weather forecasts and adoption of CSA was significant at $\left(\chi^{2} 1.23, \mathrm{P}=0.006 * *\right), 54.5 \%$ of smallholder farmers had adopted CSA due to how weather forecasts had been packaged. User friendliness of weather forecasts and adoption of CSA was significant at $\left(\chi^{2} 1.82, \mathrm{P}=0.003 * *\right), 53.7 \%$ of smallholder farmers had adopted CSA due to the user-friendliness of weather forecasts. The study findings are supported by Taneja et al., (2014) who established that utilization of weather and climate forecasts is enhanced if the information is accessed on time. Furthermore, Roncoli et al., (2008), Nyanga et al., (2011) and Anuga and Gordon (2016) assert that weather and information can easily be grasped and comprehended by the common person in villages if it is accessed and disseminated in a local language that is easily understood and is user friendly by the smallholder farmer. Oladele et al., (2019) further ascertained that weather and climate forecasts have little importance unless they are tailored enough to be used in farming decisions. They further indicated that any appropriate prediction on weather and subsequent advisory services has tremendous benefits in terms of advance management of the negative impacts of weather. This is coupled with access to the needed tools and equipment (Phillipo, et al., 2015).

Table 5: Utilization of climate and weather information and adoption of climate smart agriculture technologies in Tambacounda and Kolda

\begin{tabular}{|c|c|c|c|c|}
\hline \multirow[t]{2}{*}{ Factors considered } & \multicolumn{2}{|c|}{$\begin{array}{l}\text { Adoption of CSA } \\
\text { production practices }\end{array}$} & \multirow[t]{2}{*}{$\begin{array}{l}\text { Chi- } \\
\text { square }\left(\chi^{2}\right)\end{array}$} & \multirow[t]{2}{*}{ P-value } \\
\hline & Frequency & Percentage & & \\
\hline \multicolumn{5}{|c|}{ a) Accessibility to weather and climate information } \\
\hline Access to communication channels used & 190 & 55.7 & 2.67 & $.017 * *$ \\
\hline Information seeking behavior & 192 & 56.3 & 2.91 & $.015^{* *}$ \\
\hline Timing of forecast is favorable & 186 & 54.5 & 2.52 & $.026^{* *}$ \\
\hline \multicolumn{5}{|c|}{ b) Understandability of climate and weather information } \\
\hline Language used is easy to understand & 195 & 57.2 & 2.82 & $.009 * *$ \\
\hline Information clarity & 192 & 56.3 & 1.71 & $.015^{* *}$ \\
\hline Forecast terminologies easily understood & 188 & 55.1 & 1.21 & $.007 * *$ \\
\hline \multicolumn{5}{|l|}{ c) Usability of weather information } \\
\hline Ability to respond & 180 & 51.7 & 2.13 & $.009 * *$ \\
\hline Packaging of information & 186 & 54.5 & 1.23 & $.006^{* *}$ \\
\hline User friendliness & 183 & 53.7 & 1.82 & $.003 * *$ \\
\hline
\end{tabular}

3.6 Regression analysis of weather and climate information utilization and adoption of Climate-smart agriculture technologies among smallholder farmers in Senegal

Based on the model (Table 6), utilization of weather and climate information explained $36.1 \%$ of the variation in the adoption of CSA technologies among smallholder farmers (R square value: 0.361 ). It should be noted that accessibility significantly impacted on the adoption of CSA technologies among smallholder farmers $(\beta=0.347, p=0.004)$. This suggests that accessibility to weather forecasts increased the adoption of CSA technologies among smallholder farmers by $34.7 \%$. Further, understandability of weather information significantly impacted the adoption of CSA technologies among smallholder farmers $(\beta=0.316, p=0.029)$. This suggests that understandability of weather forecasts increased the adoption of CSA technologies among smallholder farmers by $31.6 \%$. Lastly, usability of weather information significantly impacted on adoption of CSA technologies among smallholder farmers $(\beta=0.221, p=0.005)$. This suggests that usability of weather forecasts increased the adoption of CSA technologies among smallholder farmers by $22.1 \%$.

The predictive power of the model was found to be $33.6 \%$ (Adjusted $\mathrm{R}^{2}=0.336$ ). This result indicates that the variation in accessibility, understandability, and usability of weather forecasts combined accounts for $33.6 \%$ variation in the level of adoption of CSA technologies among smallholder farmers. Nonetheless, considering the three predictors among utilization of weather and climate information in this study, the results show that accessibility has a better contribution on adoption of CSA technologies among smallholder farmers because it had ( $\mathrm{beta}=.234, \mathrm{p}=.004)$. This implies that the higher utilization of weather and climate information, the higher the adoption of CSA technologies among smallholder farmers. The regression model of adoption of CSA technologies was found to be significant $(F=22.203, p=.028)$ and hence well specified, which means that accessibility, understandability, and usability of weather forecasts were appropriate predictors of adoption of CSA technologies among smallholder farmers. 
Table 6: Regression analysis of weather and climate information utilization and adoption of Climate smart agriculture technologies

\begin{tabular}{|c|c|c|c|c|c|c|}
\hline \multirow[b]{2}{*}{ Predictors } & \multirow[b]{2}{*}{ B } & \multirow[b]{2}{*}{ Beta } & \multirow[b]{2}{*}{$\mathbf{t}$} & \multirow[b]{2}{*}{ sig } & \multicolumn{2}{|c|}{$\begin{array}{l}\text { 95\% Confidence } \\
\text { Interval for B }\end{array}$} \\
\hline & & & & & $\begin{array}{l}\text { Lower } \\
\text { Bound }\end{array}$ & $\begin{array}{l}\text { Upper } \\
\text { Bound }\end{array}$ \\
\hline (Constant) & 1.590 & & 10.862 & .000 & 1.483 & 1.697 \\
\hline Accessibility of weather information & .347 & .234 & 1.464 & .004 & .150 & .444 \\
\hline Understandability of Weather and climate information & .316 & .203 & .483 & .029 & .155 & .587 \\
\hline Usability of weather and climate information & .221 & .111 & .591 & .005 & .125 & .383 \\
\hline Adjusted R Square $=0.336$ & & 2.203 & & & Sig. 0.02 & \\
\hline
\end{tabular}

a. Dependent Variable: Adoption of climate-smart crop production practices

\section{Conclusion}

The study indicates that a substantial number of smallholder farmers access climate and weather information mainly through traditional, means of communication which are radio and television. Modern technology is also used to access weather and climate information especially through mobile phone (SMS) and searching the internet. Accessibility of weather information was high through the various media although understandability of the information received and usability of the information remained very low. Overall utilization of climate and weather information was low. The study also indicates that accessibility, usability, and understandability of climate and weather information are significant factors for the adoption of CSA. It is therefore recommended that ANACIM (National Agency of Civil Aviation and Meteorology) should make effort to ensure that the information disseminated through the various media is comprehensible which will facilitate incorporation of the weather information into the farming decision. Provision of weather-based advisory services to the farming communities to enhance utilization of information disseminated should also be implemented.

\section{Acknowledgment}

This study would not have been possible without the financial support of the African Mobility project named Regional Academic Exchange for Enhanced skill in Fragile Ecosystem Management in Africa (REFORM) program.

\section{References}

Altieri, M. A. and Nicholls, C. I. (2017) 'The adaptation and mitigation potential of traditional agriculture in a changing climate', Climatic Change, 140(1), pp. 33-45. DOI. 10.1007/s10584-013-0909-y.

ANSD (2015) Regional economic and social condition- 2013.

Anuga, S. W. et al. (2019) 'Determinants of Climate Smart Agriculture (CSA) Adoption among Smallholder Food Crop Farmers in the Techiman Municipality, Ghana', Ghana Journal of Geography, 11(1), pp. 124-139. DOI. 10.4314/gjg.v11i1.8.

Anuga, S. W. and Gordon, C. (2016) 'Adoption of climate-smart weather practices among smallholder food crop farmers in the Techiman municipal: Implication for crop yield', Research Journal of Agricultural and Environmental Management, 5(9), pp. 279-286.

Bacci, M., Diop, M. and Pasqui, M. (2013) climate control and evaluation of climate change. Senegal.

Barnard, J. et al. (2015) Barriers to scaling up / out climate smart agriculture and strategies to enhance adoption in Africa. Accra: Forum for Agricultural Research in Africa.

Belay, A. et al. (2017) 'Smallholder farmers' adaptation to climate change and determinants of their adaptation decisions in the Central Rift Valley of Ethiopia', Agriculture \& Food Security, 6(24), pp. 1-13. DOI. 10.1186/s40066-017-01001

Cherotich, K. V, Saidu, O. and Omedo, B. B. (2012) 'Access to climate change information and support services by the vulnerable groups in semi-arid Kenya for adaptive capacity development', African Crop Science Journal, 20, pp. $169-180$.

DeLonge, M. S., Miles, A. and Carlisle, L. (2016) 'Investing in the transition to sustainable agriculture', Environmental Science and Policy, 55, pp. 266-273. DOI. 10.1016/j.envsci.2015.09.013.

FAO (2013) Climate Smart Agriculture: Source book. Rome: Food and Agriculture Organization of the United Nations. (Accessed: 4 October 2020).

FAO (2015) Senegal Socio-economic context and role of agriculture.

Feleke, H. G. (2015) 'Assessing Weather Forecasting Needs of Smallholder Farmers for Climate Change Adaptation in the 
Central Rift Valley of Ethiopia', earth science and climatic change, 6(10). DOI. 10.4172/2157-7617.1000312.

IPCC. (2017) 'Summary for Policymakers. In Climate Change 2007: The Physical Science Basis'.

Kadi, M. et al. (2011) The State of Climate Information Services for Agriculture and Food Security in West African Countries: 4. Copenhagen, Denmark.

LeRoux-Rutledge, E. et al. (2010) Senegal Talks Climate.

Mutoko, M. C., Rioux, J. and Kirui, J. (2015) Barriers, incentives and benefits in the adoption of climate-smart agricultureLessons from the MICCA pilot project in Kenya. Rome, Italy. (Accessed: 5 October 2020).

Ndambiri, H. K., Ritho, C. N. and Mbogoh, S. G. (2013) 'An evaluation of farmers' perceptions of and adaptation to the effects of climate change in Kenya', International Journal of Food and Agricultural Economics, 1(1), pp. 75-96.

Nyanga, P. H., Johnsen, F. H. and Aune, J. B. (2011) 'Smallholder Farmers ' Perceptions of Climate Change and Conservation Agriculture: Evidence from Zambia', Journal of Sustainable Development, 4(4), pp. 73-85. DOI. $10.5539 / \mathrm{jsd} . \mathrm{v} 4 \mathrm{n} 4 \mathrm{p} 73$.

Oladele, O. I. et al. (2018) 'Adoption of agro-weather information sources for climate smart agriculture among farmers in Embu and Ada'a districts of Kenya and Ethiopia', Information Development, 35(4), pp. 639-654. DOI. $10.1177 / 0266666918779639$.

Oladele, O. I. et al. (2019) 'Adoption of agro-weather information sources for climate smart agriculture among farmers in Embu and Ada'a districts of Kenya and Ethiopia', Information Development, 35(4), pp. 639-654. DOI. https://doi.org/10.1177\%2F0266666918779639.

Ou, M., Partey, S. T. and Zougmor, R. B. (2018) 'Developing climate-smart agriculture to face climate variability in West Africa: Challenges and lessons learnt', Journal of Cleaner Production, 187, pp. 285-295. DOI. 10.1016/j.jclepro.2018.03.199.

Phillipo, F., Bushesha, M. and Mvena, S. K. Z. (2015) 'Women Farmers ' Characteristics and Perception towards Climate Change and Women Farmers' Characteristics and Perception towards Climate Change and Variability in Iringa District, Tanzania', Environment and Earth Science, 5(8).

Roncoli, C. et al. (2008) 'From accessing to assessing forecasts: an end-to-end study of participatory climate forecast dissemination in Burkina Faso (West Africa)', Climatic Change, 92(3), p. 433. DOI. 10.1007/s10584-008-9445-6.

Serra, R. and Mckune, S. (2016) Climate information services and behavioral change: The case of Senegal. 10.

Sivakumar, M. V. K. (2006) 'Climate prediction and agriculture : current status and future challenges', climate Research, 33 , pp. 3-17.

Sovacool, B. K., Linnér, B. and Klein, R. J. T. (2017) 'Climate change adaptation and the Least Developed Countries Fund ( LDCF ): Qualitative insights from policy implementation in the Asia-Pacific', Climatic Change, pp. 209-226. DOI. 10.1007/s10584-016-1839-2.

Taneja, G. et al. (2014) Farmers' preferences for climate-smart agriculture an assessment in the Indo-Gangetic plain - IFPRI Publications - IFPRI Knowledge Collections, Food Policy Research Institute (IFPRI) Discussion Paper 01337. (Accessed: 4 October 2020).

Taneja, G. et al. (2019) 'Farmers' Preferences for Climate-Smart Agriculture-An Assessment in the Indo-Gangetic Plain', in Pal, B. et al. (eds) Climate Smart Agriculture in South Asia. Singapore: Springer, Singapore, pp. 91-111. DOI. https://doi.org/10.1007/978-981-10-8171-2_5.

UNDP (2006) Plan d'action national pour l'adaptation aux changements climatiques. Senegal.

Zougmoré, R. et al. (2016) 'Toward climate - smart agriculture in West Africa : a review of climate change impacts , adaptation strategies and policy developments for the livestock, fishery and crop production sectors', Agriculture \& Food Security, pp. 1-16. DOI. 10.1186/s40066-016-0075-3. 